\title{
The Structure of Jhum (Traditional Shifting Cultivation System): Prospect or Threat to Climate
}

\author{
Kaushik Bhagawati $^{1^{*}}$, Goutom Bhagawati ${ }^{2}$, Ranjan Das ${ }^{3}$, R. Bhagawati ${ }^{1}$ \\ and S.V. Ngachan ${ }^{4}$ \\ ${ }^{1}$ ICAR Research Complex for NEH Region, Arunachal Pradesh Centre, Basar-791101, India \\ ${ }^{2}$ KVK, Gossaingoan, Assam-783360 \\ ${ }^{3}$ Department of Plant Physiology, Assam Agricultural University, Jorhat-785013 \\ ${ }^{4}$ ICAR Research Complex for NEH Region, Umiam, Meghalaya-793103 \\ *E-mail address: kaushik.iasri@gmail.com
}

Keywords: Jhum, climate change, biodiversity, carbon sequestration, indigenous knowledge.

\begin{abstract}
The knowledge behind the culture and beliefs of indigenous community needs to be harnessed and should be used to complement the modern technologies and policies for better and sustainable use of biological resources and increase resilience of the sector associated. The main objective of the current research was to study Jhum (Traditional Shifting Cultivation System) and the cycles and culture associated with it. The study was done in northeast Himalayan region of India and phenomenological approach was used. The research reveals that Jhum is the component of traditional agro-ecosystem encompassing diverse set of knowledge and practices of indigenous and local communities embodying traditional life-styles relevant for the conservation and sustainable use of natural resources for their livelihood. The cycle associated with the system reflects the synergy of practices with the natural phenomenon and indicators. Contrary to common modern belief, Jhum is carbon sink, maintain soil health, preserve biological diversity and sustain local climate. Forest clearing during Jhum is not deforestation but forest modification allowing forest regrowth during sufficiently long fallow. Fundamentally, Jhum as a system is an integrated approach to establish agro-ecosystem in the difficult terrains of tropical hill regions that involve forest, soil, biodiversity and livestock management through their culture, tradition and rituals that coevolved with associated ecosystem. Instead of being threat to climate or environment, the system can provide deeper insight into the many different aspects of sustainable and climate resilient development; and the interrelated role of local peoples and their cultures.
\end{abstract}

\section{INTRODUCTION}

Science and scientific studies needs and demands diversity. No rule is the only rule of universe, no two events or things are exactly similar in the universe. There are no ideal or general conditions in nature; but full of diversity in all levels and locations. Something is there or something exists if we observe (sense) it and define it, and science begins if we try to understand the phenomenon behind it through continuous observation. The reasoning developed through these continuous observations is the knowledge about the subject. The knowledge when transmitted to generations becomes "belief" with experience. When we practice and live with this acquired knowledge, it becomes our culture which is our common beliefs and attitudes about certain event/thing/phenomenon sharing same location or environmental conditions [1]. Thus observation is seed of knowledge and repeated observation refines it. Here we can say that it is observation and reasoning about certain subject or object followed by quest to find logic behind that reasoning through some repeatable steps is "Research". If science is knowledge about structure and behaviour of the natural and physical world or study of universe and its phenomenon through observation and experiment [2], there should not be some specific rules or standards in science. To study such diverse world we need diverse context based approaches or methods, without following certain similar procedures. We cannot and should not define science in a box or bound it in some definite 
well define procedures and validate it by some statistical methods. The approaches need to be task or entity specific. What is visible or obvious may not be the fact all the time (when viewed without being the part of the system), in fact is not the fact in most of the time. In the pursuit of science or knowledge, the approach should be inclusive of all possible facet of the entity under investigation, and knowledge must also include know-how. Though experiments and statistics are required to support any findings but they should not be the determining factor. There are many facts and figures, may not be measurable or countable, but are the root of natural phenomenon and relationship. There should not be "no looking back" in science, we have to look back and if necessary we have to even go back. Go back to understand the event or entity in a new way or understand additional vital facts that we missed earlier, that created current crisis. Out of the innumerable examples, the environmental setback due to Industrial Revolution in Europe [3] and agricultural setback due to Green Revolution in India [4] were prominent.

Anthropogenic climate change and its impact is fact [5], though with spatially varied intensity, with evidences from increase in average air and ocean temperatures, melting of snow and ice and sea level rise. Now there is no need of any proof or declaration of climate change by some organization or institution; it can be felt and can be experienced. The very impact of the climate change in all the sectors, especially those that depend on ecosystem services are apparent. We now have to search the nodes where we missed the links and reassemble those links to define and shape our development in an environment friendly and sustainable way. One very important node is Indigenous Traditional Knowledge (ITK) which was neglected and tagged as primitive, but recently, it is getting much attention. The IPCC's Fourth Assessment Report (AR4) [5] noted that 'indigenous knowledge is an invaluable basis for developing adaptation and natural resource management strategies in response to environmental and other forms of change' [6]. Also, UNFCCC (2011) [7] recognizes the conservation of traditional knowledge as co-benefits of ecosystem- based approaches to adaptation. The Institute of Advance Studies at the UN University recently identified more than 400 examples indicating the role of indigenous people in climate change monitoring, adaptation and mitigation [8]. The sustainability of the indigenous knowledge system lies on the fact that they were accumulated incrementally, tested by trial-and-error and transmitted to future generations orally or by shared practical experiences [9].

Here in this study, by highlighting ITK we are not trying to compare or condemn modern scientific systems but we are trying to find way out how science of ITK can be harnessed to complement the modern policies and strategies to make them more acceptable and increase participation. Especially for climate change mitigation and adaptation strategies, integration of indigenous knowledge can lead to the development of effective and robust strategies in a very costeffective, participatory and sustainable way [10,11]. It is an attempt to find sense out of nonsense, science out of superstitions and knowledge out of culture. It is also an effort to demonstrate that this knowledge-practice-belief complex [12] is science blending both concrete and abstract. The study mainly focus on ITK associated with the Jhum (shifting cultivation) in its originality, being practiced mostly in tropical hilly areas of Southeast Asia, the Pacific, Latin America, the Caribbean, and Africa for millennia [13,14,15] and was estimated to be the means of subsistence for at least half a billion people [16]. Though Jhum has been continuously targeted as threat to climate $[17,18,19,20,21]$, but in fact it is a promising prospect for climate change mitigation and adaptation. The validation process of modern science is based on scientific criteria that purportedly make distinction between useful from useless, objective from subjective, indigenous 'science' from indigenous 'beliefs'. Through this process, knowledge corresponding with the paradigm of Western science is extracted, and the rest is rejected [22]. This approach hurdles study of Jhum as a knowledge system that can provide resources for the future climate change mitigation and adaptation strategies. Before giving the rationale behind the current study, there needs to broaden the definition of certain terms under the given context. 


\section{DEFINITION OF 'JHUM'}

The word Jhum may be the most misunderstood term among the environmentalists, scientists and others concerned with natural resource management. The most commonly shifting cultivation is defined as any agricultural system in which the fields are cleared (usually by fire) and cultivated for shorter periods than they are fallowed [23]. Jhum is not synonymous with 'slash-burn agriculture' or it is not just a land-use system where forest is slashed and burned to make arable land for a particular period. In fact slush-burning is a land clearing method and is employed also for other agricultural and non-agricultural land clearing [24]. However, Jhum is a component of traditional agro-ecosystem encompassing practices derived from ages of observations to interact with the environment in most harmonious manner that took the form of traditions, customs and rituals that governs agriculture in a most cultural and sustainable way where land is cleared by means of controlled fire and employ natural fallow phase long enough to be dominated by woody vegetations. As pointed by Geist and Lambin (2001) [25], Jhum or traditional shifting cultivation (swidden-fallow farming) is very much different from shifting cultivation practiced by the migrant settlers (slash-and-burn agriculture by in-migrants). So it is very important to keep in mind that all shifting cultivation is not Jhum. And the most fundamental difference is that they are practiced by different group of people with wide variation in their culture and relationship with ecosystem.

\section{DEFINITION OF 'CLIMATE CHANGE'}

"Climate change in IPCC usage refers to a change in the state of the climate that can be identified (e.g. using statistical tests) by changes in the mean and/or the variability of its properties and that persists for an extended period, typically decades or longer" [5]. But for biological world, Climate Change is not just change in statistical distribution of weather patterns over a considerable period, but change in any factor in the immediate environment or global conditions that have impact on the stability of that particular ecosystem. It is not just change or variation in weather parameters like temperature, rainfall, wind etc but it must also include change in the immediate environment or ecosystem due to some new introduction of plants or/and animals, change in soil compositions, change in population \& its distribution, change in perception \& behaviour of the inhabitants etc. Climate in this sense is the sum total of factors that preserve the original identity of the location under consideration for a considerable period.

Jhum involves fire for clearing forest and consequently emits carbon into the atmosphere, thus considered to be detrimental to climate change [26,27] and is coming under increased pressure. It is largely viewed as an exploitative system involving poor management of natural resources and major factor behind deforestation, biodiversity loss and ecological instability. Its uniqueness from the rest of the cultivation practices in the plains by majority of the population account for it being widely misunderstood and misinterpreted. It is recognised as the practice of the primitive people and those who are outside the mainstream culture responsible for the wasteful use of resources [28]. However, the studies in the recent time agree that the effect of Jhum was greatly overestimated based on insufficient and erroneous information [29,30]. Also the role of Jhum is being recognized for ecologically sustainable and economically viable form of agriculture [30,31]. Though the practice was considered to be major factor for loss of biodiversity and imbalance in the ecosystem, but the fact remains that the majority of the world mega biodiversity area coincide with the area occupied by the indigenous people practicing similar system of agriculture from ages [32].

Current work never intended to nullify the findings and study of pervious research, but to draw attention towards some untouched and neglected aspects of Jhum cultivation that deserve through revision for sustainable management of ecosystem. It is to study the matrix i.e. the social, cultural and environment conditions under which Jhum developed. Jhum is not only an agricultural land use system for these indigenous peoples but is their way of life, with all their customs, rituals, festivals and heritage closely associated with it. The difficult topography, inhospitable terrain, incessant rains and harsh climatic conditions in the hilly regions led the people to adopt this age old practise. It is their cordial response to the difficulties in establishing an agro-ecosystem in the 
difficult tropical forest ecosystem that is characterised by generally poor acidic soils and a diverse flora \& fauna leading to many potential competitor species for the food crops. The system was found to be economically and energetically efficient compared to other form of agriculture (terrace or valley cultivation) in heavy rainfall areas of the hill tracts [33]. The underlying science in selection of location, planting date, selection of crops \& varieties, cultural management practices etc. warrant lot of research and study. The most noteworthy fact is though this slush-burning practice is being practiced from centauries in these hilly regions but still they have same evergreen diverse forest meeting all their resource need for livelihood right from house construction to medicines in a very sustainable way. The investigation is done to study the Jhum cultivation in general and peep into the science behind its sustainability, and the sustainability of ecosystem associated with it.

\section{MATERIALS AND METHODS}

\section{Study site}

The initial survey was done in almost all the hilly region of the Northeast Himalayan Region of India located between E $89^{\circ} 36^{\prime} 16.1719^{\prime \prime} \mathrm{N} 26^{\circ} \& 22^{\prime} 19.8676^{\prime \prime}$ to E $97^{\circ} 19^{\prime} 0.8203^{\prime \prime} \mathrm{N} \& 28^{\circ}$ $8^{\prime} 58.2116^{\prime \prime}$. The surveys were made during different seasons so as to cover the various stages of the Jhum cycle. The climate of the region varies abruptly due to varying topography. The study sites mainly come under tropical climate with further division of mid and sub-tropical. The region receives world's largest rainfall with intra-regional variations.

\section{Methodology}

The phenomenological approach was used to study the various cultural system associated with Jhum. The approach was chosen principally because it evaluates and analyses natural behaviour and instinct, as the indigenous communities perceived it rather than imposing any sort of external value judgment [34]. The means and techniques through which the local people as "insider" come to know about some phenomenon can be investigated through this approach [35]. The approach also helps to differentiate noumena (things as they are) from phenomena (things as we perceive them). So first hand information was collected through interactions with farmers of various groups in their fields. The Jhum cultivation practices were closely studied right from land selection to storage. All the rituals and ceremonies related to the system were observed closely. Nearly 26 villages from 4 different states are covered during the investigation across the region and 166 numbers of farmers and other villagers were interviewed. The daily work calendar and cropping calendar of the different groups of farmers were collected and studied closely.

\section{RESULTS}

\section{Jhum Calendar}

The major stages of the traditional Jhum cycle in general are: site selection and clearing, burning, sowing, weeding, protection, harvesting and storage. Special and crucial decision concerning the location, scheduling, crops and the labour inputs needs to be taken in each stages of cultivation. This decision making process is very vital in the process and, though needs to take care of the agro-climatic and environmental conditions, and are also moulded by the social and cultural factors. The decision makers largely depend on the natural indicators for making vital decisions. Each tribe have some location-specific traditional calendar of events for Jhum with different local names. A distinction is made by the native tribes in the pattern of Jhum based on the locality where it is undertaken. Even within the same location, each site was found to have characterised by different time of sowing, harvesting etc. depending upon altitude of the site and vicinity to habitat. Further the fellow cycle is also very location-specific depending on nearby forest type and soil of the selected site.

Jhum cycle have a very interesting and nature-scientific relation with the natural indicators that worth further systematic study. Normally the Jhum cycle begins in the month of December- 
January with calls of some particular bird (Chou pou) or insects (Goi) or other location specific indicators. This cycle involves selection of new plots based on presence/absence of some selective vegetation. The selection criteria also depend on soil type of the area and nature of crop planned to grow. Some sites are considered to be sacred due to presence of some rare vegetation and likewise some areas nearby villages are considered to be cursed and cutting of trees in such area is strictly prohibited. Some tribes before felling of trees in common wastelands, they seek permission of deities. On one hand their mercy is sought for felling the tree and on the other they are thanked for rearing the tree for so long. During clearing of the forest they avoid cutting of some particular tree species so as not to invoke the spirits of the woods. A particular mention may be made of Sengri \& Sengne (Ficus sp.) [36], which are considered to be the abode of sprits and to cut them or to use their wood as firewood is tabooed. It is followed by cutting and slashing of under growth, shrubs, twigs and trees. Cutting and Slashing are done by a selected group of skilled persons, and they use to cut trees of medium girth up to certain height keeping in mind the crop variety that they are planning to grow at that particular site and keep the height of slashed trees 6-8 inch lower than the expected height of the crop at its maturity. And also they were found to be uniformly distributed throughout the field. The next cycle is in the months of January-February with calls or coming of Pipiar birds or blooming of certain wild flower like Bombax ceiba, and the cycle involves burning of slash and clearing of charred remains. Very strict customs were followed while burning the slashed field in which the persons responsible are not supposed to take full meal and the event is celebrated overnight. The resulting ash was uniformly distributed throughout the field (Fig. 1). This stage also involves sowing of some early paddy and other location based crops. The months of February-March are the third cycle that begins with singing of Pakyo tabo bird and flowering of Mekahi (Phoebe Cooperiana). The main activities involve terracing of steep slopes and higher areas, along with contours with half burnt old logs, weeds, stems, etc. (Fig.2). Mainly sowing of maize is done during this period. In March-April, sowing of some vegetables like cucumber, cucurbits, chillies, ginger, beans, tapioca etc are done randomly mainly in the boundaries. Different tuber varieties are sown along the peripheries that act as live fence for protection against animals. Mithuns (Bos frontalis), the most important domesticated herbivore animal is generally kept under temporary community confinement called Lura during the growing season [37]. Chirping of Tuk pi pipi and pinching birds starts the next cycle during the months of April-May that goes on till the time the frog starts croaking. Here the main activities involve weeding in pervious crops and sowing of paddy. The paddy is shown by dibbling techniques where farmers make a small hole with the help of a sharpen stick and drops two-three seed into the hole with expertise that they gain with years of experience and practice (Fig. 3). Sowing of paddy in some place also coincide with flowering of Gynocardia odorata known locally with different names. The sowing is mainly done by women folks and it involves minimum disturbance of soil. Almost all their festivals and rituals revolve around Jhum and they keep close monitoring over their field for weeding and other activities. The harvesting is done generally in the months of October-November in which the women plug the head of rice bunch and carry them in bamboo basket called Egin. The dried grains are stored in specially built rodent free granary called Nehu. Before using the new grains for food, they very religiously keep some portion of grains separately for future seed. Mixing seed of different variety is tabooed.

\section{Cultural Practices}

They keep close monitoring over the weather to schedule their activities of weeding and harvesting with the help of certain birds, insects and other natural indicators. An insect such as annual cicida is considered to be best for short range weather forecasting. With its unique singing pattern they can predict weather for next 2-4 days with near accuracy. Their sowing, harvesting and other vital activities are also significantly influenced by lunar cycle. Moon is considered the goddess of fertility and deity of flora \& fauna. They schedule their activities, mainly sowing and harvesting, according to phases of moon. Days near the vicinity of Full Moon are considered ideal 
for sowing seeds to avoid insect attack and also they believe that the soil moisture is high during the days at the vicinity of Full Moon.

The indigenous Jhumias (Jhum cultivators) are very reluctant in adopting foreign crops and varieties. They have their own varieties of paddy, maize and vegetables that they preserve from generations. Depending on the weather, site and soil, different varieties were sown. Preservation of seed for future crop is considered to be their spiritual responsibility and women folks are mainly responsible for the task. They generally have huge repository of germplasm of each crops.

A single site is generally sown for 3-5 years depending on the soil fertility of the site and nature of crops grown earlier. The minimum fallow duration is generally 15 years that too they decide after proper investigation of the vegetation type and stem diameter of the recovered plants.

\section{DISCUSSION}

The biodiversity conservation is always been in the forefront agenda of indigenous community practicing Jhum. However, Jhum was widely condemned as threat to biodiversity: both natural and agricultural [38]. The indigenous Jhumias maintain natural biological asset balance (the assets whose initial form was determined by ecosystem of the location) rather than giving more priority to some selected groups of biological assets. During the site selection for Jhum they strictly avoid those locations that are dominated by rare or/and medicinally important plants. They avoid felling certain big trees (regarding them as abode of sprit) as they knew its significance to immediate ecosystem and its sustainability. Such big trees also provide habitat to innumerable birds, animals and insects who are their guide in agricultural activities. Associating such practices with rituals and customs make them moral and spiritual responsibility of the society and individual. Site selection based on some indicator plants was also reported in Malaysia [39]. They worship the forest as protector; feeding and rearing human being [40]. Unlike modern strategies, the concrete and the spiritual co-exist side by side in the indigenous community, complementing and enriching rather than competing and contradicting [22]. The term 'Biological Diversity' encompasses virtually limitless subjects: cultural preservation, habitat preservation, species preservation etc [41]. Jhum is concerned not only with the preservation of flora-fauna, but those culture and traditions that evolved as a result of interdependence of the inhabitant with their immediate environment. It also induces understanding of nature and its phenomenon and their impact on society today and tomorrow. They have very cordial relationship with the seasonal birds, insects and animals; and are considered to be messenger of weather and fertility god, thus indiscriminate killing is strictly prohibited. The indigenous community socialize the natural phenomenon and social phenomenons are described in ecological terms [42]. The Jhumias consider themselves inside the system (ecosystem) which is by its nature a diverse system. Biodiversity is the major source of information and people gathers information by interacting with their immediate biological environment [43].

In the biologist's sense of the world, biological diversity is the natural stock of genetic material within an ecosystem [41]. The importance of genes lies on the fact that they determine the particular characteristics of a given organism and encode the information which determines the specific capabilities of that organism. Greater the varieties in the gene pool, greater are the variety of organisms, characteristics and traits. Beside forest biodiversity, agricultural bio-diversity is maintained by Jhumias. They preserve their original crop varieties in a very religious way. They also use to grow diverse crops or varieties as per land location and possible weather conditions. They have a huge repository of germplasm which they maintain as per their culture and tradition. Under the given environmental condition, a species is best to its own niche [44]. The region under investigation is the centre of origin of important crops like citrus, rice, etc. [45]. The crop wild relatives and landraces maintained by indigenous community have been considered to be essential to future viability of global food production irrespective of climate change [46]. It is the people and the practices associated with them, not the landscapes, conserve agricultural diversity. The hesitation of indigenous Jhumias in adopting foreign varieties is a great step towards biodiversity conservation because the uniform cultivated varieties that are now substituted for the resident diversity worldwide is posing major threat to biodiversity [41]. Studies found that the lake of 
adequate stock of the species from which it might regenerate itself has been the major reason behind any species being endangered [47]. Traditional management system like use of more varieties, species and landscape patches helps in conservation of biodiversity as found in several studies across the globe [48,49]. Ramakrishnan (1992) [33] describe mixed cultivation system especially in Jhum, in which some of the species help maintain ecosystem structure and function.

Grazing management through Lura is another innovative technique of biodiversity conservation of Jhumias, in which during the cropping and growing seasons all the Mithuns (Bos frontalis) of the community are temporarily confined in a sufficiently large selected site (that provide adequate food and water) which is changed every year. The confinement checks Mithuns from continuous, free and random grazing of forest vegetation during the growing season [37], besides protecting Jhum fields. During the growing and rainy season the confinement of Mithuns in Lura avoid disturbance of soil surface due to treading that check soil erosion and compaction; and allow free regeneration of grazed vegetations as well as seedling germination throughout the forest.

Jhum is mainly targeted as threat to climate change as it relies on fire [50,21], thus emitting carbon dioxide into atmosphere enhancing atmospheric concentration of greenhouse gases [27]. Fire and land \& natural resource management are indispensible for indigenous people. Indigenous people promote diversity of habitat by regular burning of parts of ecosystem thereby increase stability and sustainability [51]. In fact fire has been used by the indigenous people as a tool to manage diverse ecosystem [52]. The Jhumias never go for reckless burning of slashed area. They know the science to control the fire and the ceremony keep them awake whole night so to avoid spread of fire. They avoid full meal during the time which may help them to avoid sleep. Also the ash increases the fertility of soil and help to lower the acidity of the soil which is the major constraints in the soils of hilly regions having high rainfall. Previous studies indicated that ash addition to the soil after burning mitigates the soil acidity and increases fertility $[53,54,55]$.

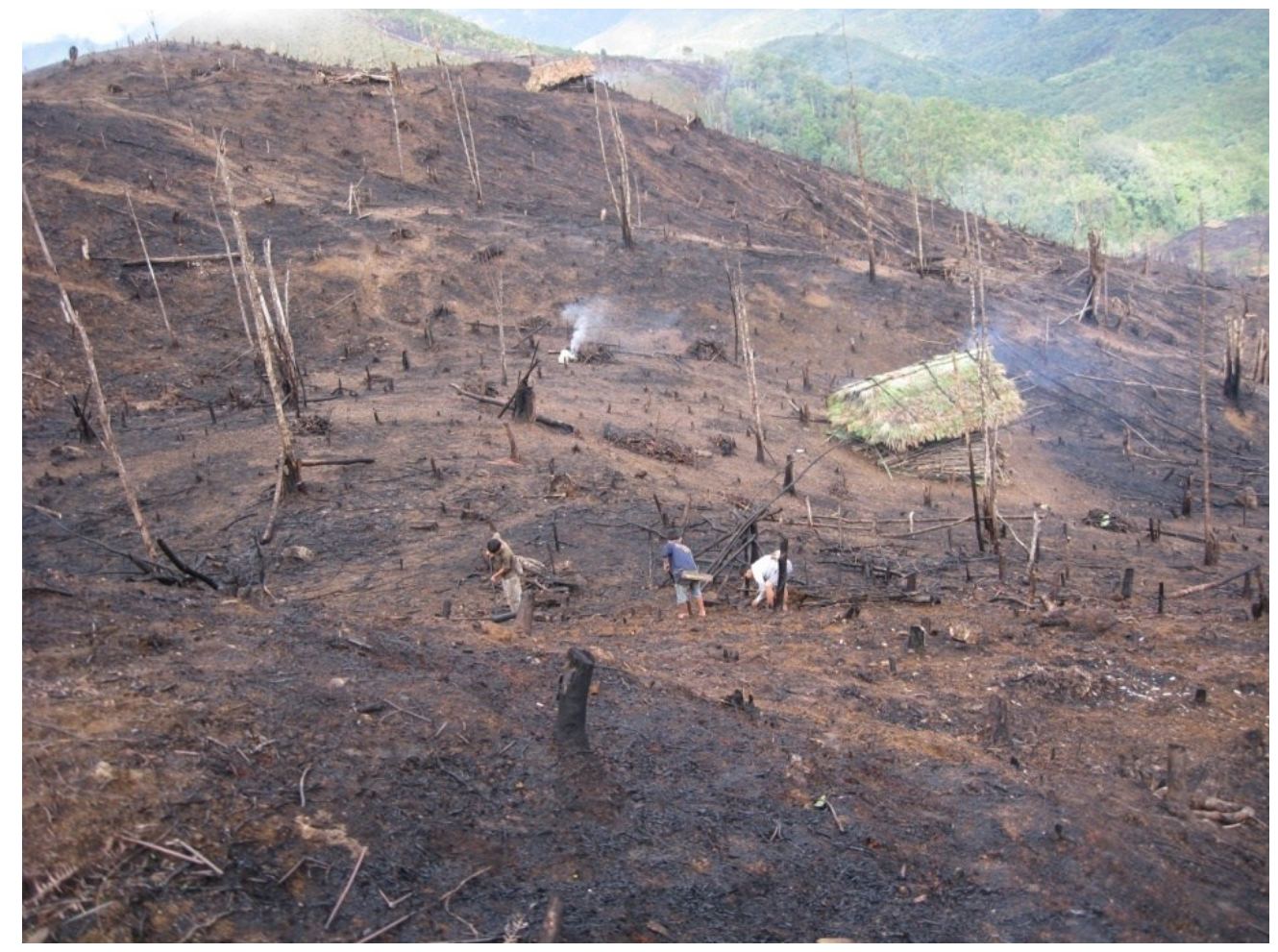

FIGURE 1. DISTRIBUTION OF ASH UNIFORMLY THROUGHOUT THE FIELD AFTER BURNING 


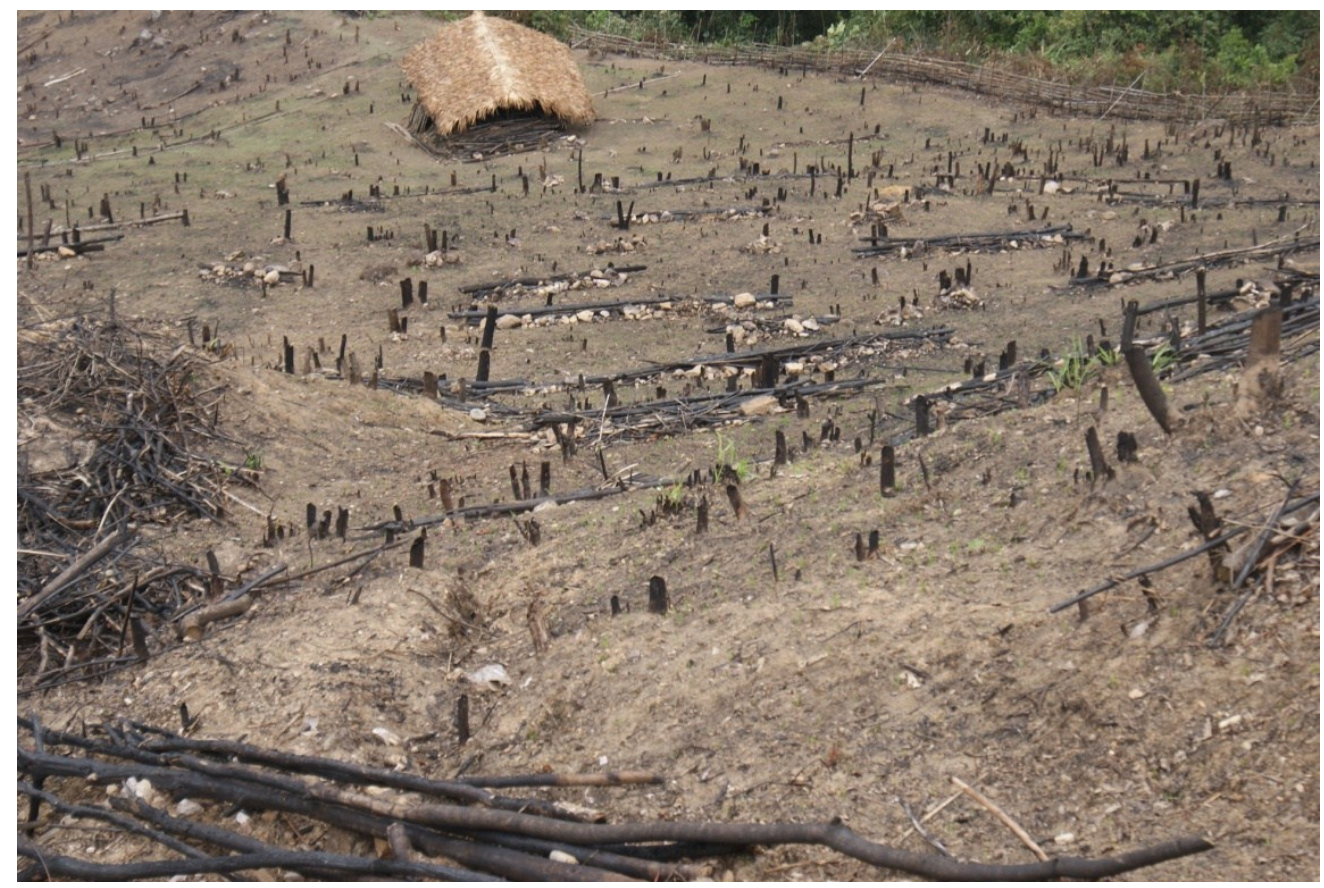

FIGURE 2. HALF BURNT BRANCHES LAID ACROSS THE SLOPES FOR PREVENTION OF SURFACE RUNOFF AND SOIL EROSION

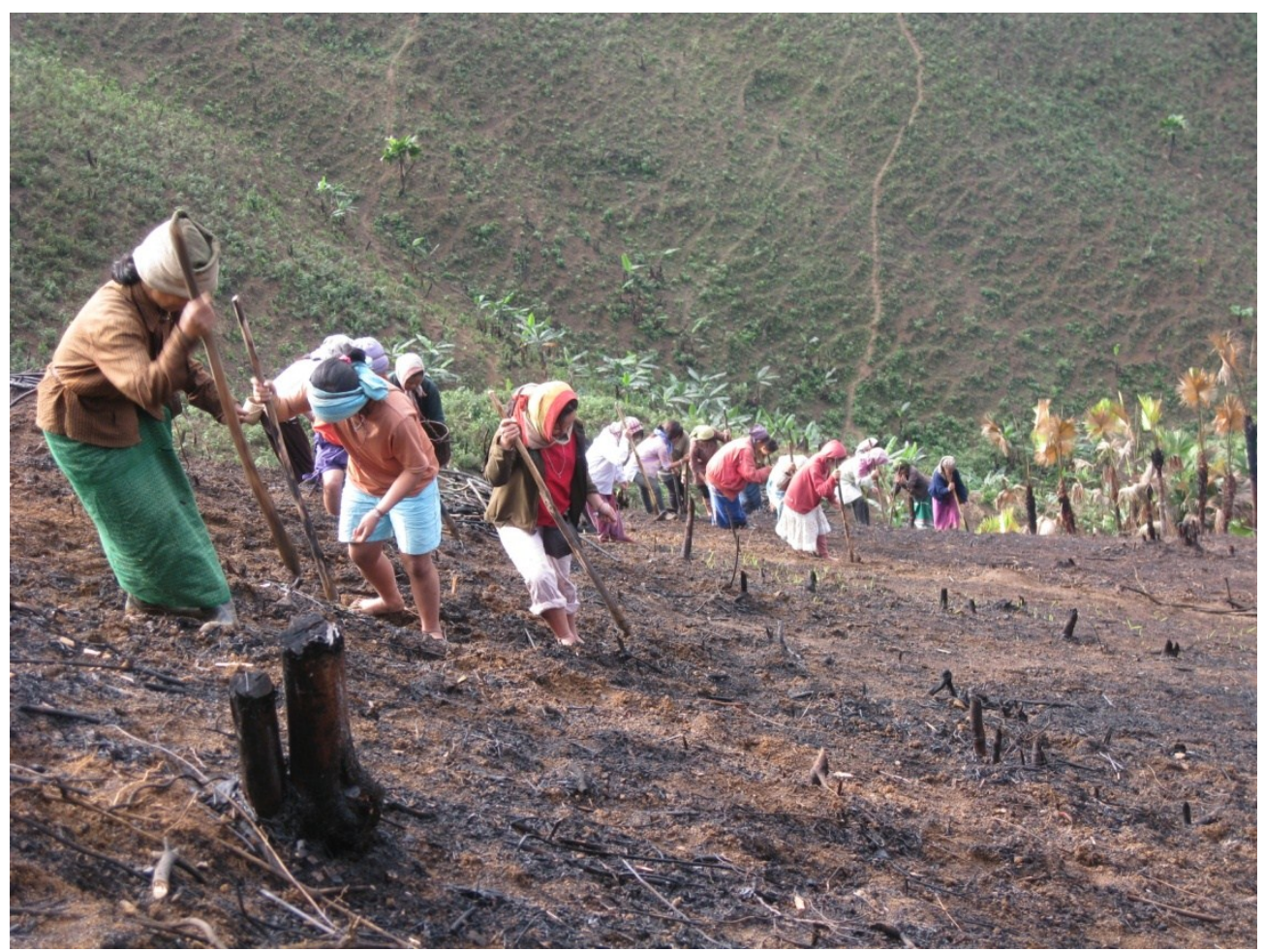

FIGURE 3. SOWING OF SEEDS BY DIBBLING METHODS MAKING HOLES WITH SHARPEN STICKS 


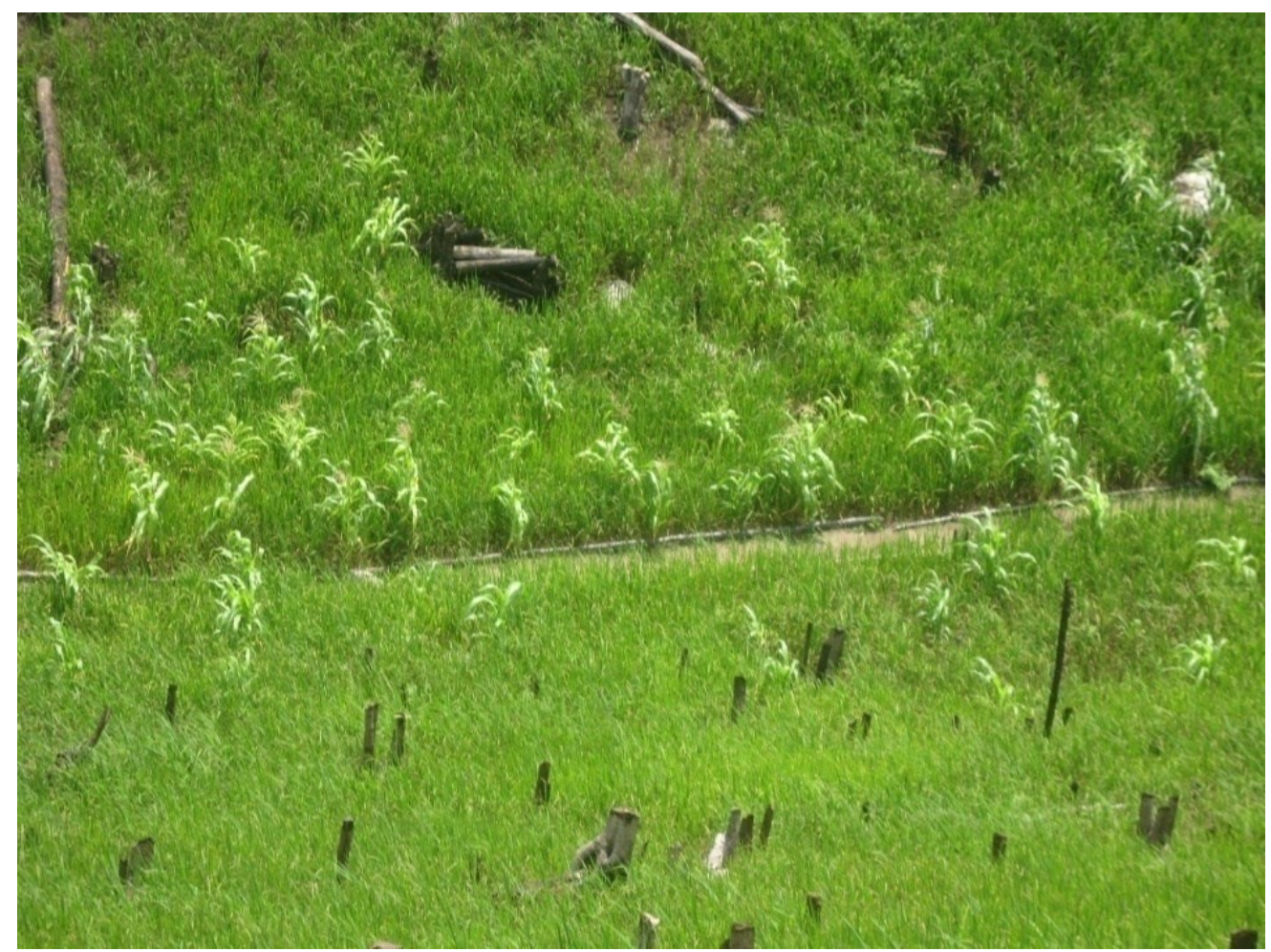

FIGURE 4. SLASHING MEDIUM GIRTH PLANTS TO A CERTAIN HEIGHT DEPENDING ON THE EXPECTED HEIGHT OF THE CROP FOR INSECT CONTROL

Jhum is considered to be one of the major factors of deforestation and forest degradation [56,57]. But deforestation implies long-term (>10 years) or permanent loss of forest cover [58]. As per the definition of deforestation by FAO [59], the clearing of forest for Jhum is not deforestation but it is "forest modification". As indicated by van Noordwijk et al (2008) [60], clear-felling and replanting is normal forest management either naturally or artificially, as long as the re-growth is allowed to attain woody vegetation. On the contrary, by definition, if the slashed-burn land is converted for intensive agriculture it can be declared as deforestation.

The GHG emission (which is mainly carbon dioxide) during Jhum is not at all a luxury emission. Also if we consider whole budget of carbon dioxide $\left(\mathrm{CO}_{2}\right)$ emission of Jhum, the net emission is negligible [61,62]. Whatever is emitted during burning is nullified by land use, chemical-free managements, almost permanent land cover with alternate crops, non-flooded fields, forest regeneration in left out sites etc. The forest clearing for shifting cultivation releases less carbon than permanent forest clearing because fallow period allow forest re-growth [63]. It was found in the previous studies that if the fallow periods are long enough, shifting cultivation can be carbon neutral maintaining soil fertility [64,60]. Tillage can cause loss of significant amounts of carbon (lost as $\mathrm{CO}_{2}$ bursts) immediately after tillage [65]. Reduced tillage or zero-tillage practices were found to decrease net emissions of carbon dioxide from soil [66,67] also retaining plant residue on the soil surface. The dibbling method of sowing by Jhumias is zero tillage emitting practically no carbon dioxide and retains soil organic matter (Fig. 3). Minimum disturbance of soil also lowers soil erosion and surface runoff. Soil erosion is also controlled by placing the half burn logs across the slopes of the field that lowers the speed of running rain water and retain the top soil (Fig. 2). Thus, Jhum also reduce $\mathrm{CO}_{2}$ emission by avoiding soil erosion. Studies found that exposure of soil organic carbon to aeration during soil erosion increases $\mathrm{CO}_{2}$ emissions. Soil erosion and degradation been never been an issue with Jhum cultivation though highlighted widely $[68,69]$.

An over-emphasis on sequestering carbon in soil as a means of climate change mitigation may eclipse other issues that are at least as significant. One such issue is to identify ways to decrease emissions of non- $\mathrm{CO}_{2}$ gases from agricultural practices, in view of the estimate by the 
IPCC (2007) [5] that 70\% of the total GHG emissions from agriculture are associated with nitrogen fertilizer that released $\mathrm{N}_{2} \mathrm{O}$ which has so and so times $\mathrm{GHG}$ potential compared to carbon dioxide. Chemical free cultivation and management practices results almost no emission of such gases during Jhum. Their system of cultivation is absolutely organic and natural, using only farm residues, animal wastes etc. Most of their insect and pest management strategies are based on performing field activities with natural phenomenon and indicators. They have very good understanding of insect pest and disease dynamics through ages of observations. They lower incidence of insect and pest by proper selection of date of sowing and other cultural management depending on lunar cycle. Sowing during the days in the vicinity of Full Moon found to lower insect attack and favour germination. Slashing medium girth plants to a certain height depending on the expected height of the crop to be shown is a unique insect control technique of Jhumias. During initial growth of the crop especially rice, the stumps acts as platform for birds to sit and feed on the insects in the leaf of crop, but when the plant grow to maturity it outgrow the stamps and avoid birds from feeding on its grains (Fig. 4). Burning of vegetations at Jhum sites besides adding carbon to the soil, also help neutralization of soil acidity. Soil acidity may be one of the main reasons of prevalence of diseases and pests in these areas, but burning not only control soil acidity but also help to get rid of spores of pests in the soil.

The Jhumias are very particular about fallow period and 15 years fallow was found to be sufficient for regeneration of vegetation and rejuvenation of soil. For the tropical forest the fallow period of minimum 10 years is generally sufficient for the recovery of the vegetation, but it depends on the nature of soil and vegetation [70]. The inspection of stem diameters of the recovered plants indicates the rejuvenation of the soil and the vegetation [39].

Thus the questions remains- why Jhum or other systems related to indigenous community were always targeted for any environmental degradation or crisis? Are the allegations having some logic or it is just shifting of blame? why our modern development policies and technologies in some way or other, now or then, here or there pose challenges to the natural environment or climate, while some age old indigenous practices are so sustainable and maintain diversity of ecosystem from antiquity? How we define development? Is development a uniform process? Where and what we are lacking fundamentally in our modern policies and strategies?

One of the most fundamental as well as visible implications of the modern human development has been the conversion of the naturally existing forms of assets to form that are preferred and valued most by the human societies [71]. Development become homogenous process over the past ten thousand years, where same developmental strategies were implemented across the globe where conversion was done by replacing the naturally existing slate of species with a selection from the same small menu of specialised species uniformly replacing the resident strategies and varieties. These lead to relative decline in diversity and resilience of the society. Domination and manipulation of nature by human activities become the definition of development. On the contrary the rituals and traditions of the indigenous people aims in conserving diversity in all aspects (biological, cultural, natural, social etc.) as it is in situ. The world around us has been changing and would continue to change; the pro-nature system increases our adaptation and resilience to these changes. Adaptation and resilience as a whole are gradual processes representing millions of ups and downs for a particular community or ecosystem [42]. The approach of Jhumias reflects that their culture coevolved with environment to create a sustainable food procurement system [72].

\section{CONCLUSION}

The indigenous inhabitants consider them as an indispensible part of the immediate environment and understand the role of every entity for its survival. They value the natural indicators like birds, trees, insects, animals and other natural phenomenon and follow their instinct to plan their activities. These help them to respond towards the irregularities of the weather and other natural events. The customs and traditions associated with Jhum cultivation phases safeguard their practices and systems leading to protection of climate. The deity or sprits are in fact some tools 
or mechanisms to implement their regulations over protecting certain landforms or some species that are vital for the ecosystem. All events and stages are marked by some symbols to associate some complicated events with the activity in a very logical or scientific manner. Biological diversity is not only a physical or environmental issue for Jhumias, but it also concern with diversity in thinking and perception. This very diversity helps native people to employ need-based strategies in case of adverse environmental and climatic conditions; and make them and their system resilient. Thus we can conclude that Jhum is prospect for sustainable development and climate change mitigation and adaptation. The structure of Jhum clearly depict that climate, ecosystem and species are one and the same representing a system, and change in any one of them leads to change in whole system. During the study it was observed that Jhum encompasses a complete body of knowledge, know-how and practices maintained and developed by peoples, generally agrarian in nature, who have extended histories of interaction with the natural environment. It provides the basis for local-level decision making about agriculture and adaptation to environmental or social change. In understood properly, instead of being threat to climate or environment, the system can provide deeper insight into the many different aspects of sustainable development and the interrelated role of local peoples and their cultures. It has great potential to strengthen the modern developmental programmes and make them sustainable and acceptable. It is our conviction that greater efforts should be made to identify the local specific knowledge, understand the rationale behind them, strengthen the adaptive capacity of local people by developing policies and projects with room for local knowledge base, and to develop methodologies that promote activities for improving livelihoods in a sustainable way.

\section{Acknowledgement}

We specially thank the farmers of West Siang District of Arunachal Pradesh who indeed have deep understanding of environment and climate and for their help in the entire endeavour. We bow our head towards their rituals and customs which are scientific and may be beyond modern science. Thank you all.

\section{References}

[1] Oxford Advanced Learners Dictionary. (2005). Oxford University Press, Great Claredon Street, Oxford, UK.

[2] http://www.oxforddictionaries.com/definition/english/science

[3] Mjøset, L. \& Kasa, S. (1994). "Environmental problems and techno-economic paradigms, a contribution to the history of environmental problems". In R. Delorme \& K. Dopfler (eds.): The Political Economy of Diversity, Edward Elgar Publishers, London, pp. 167-199.

[4] Singh, R.B. (2000). Environmental Consequences of Agricultural Development: a case study from the Green Revolution state of Haryana, India. Agriculture, Ecosystem and Environment, 82: 97-103.

[5] IPCC, Summary for Policymakers, Fourth Assessment Report (AR4). (2007). New York, Cambridge University Press

[6] Parry, M.L., Canziani, O.F., Palutikof, J.P., van der Linden, P.J. \& Hanson C.E. (eds.) (2007). Contribution of Working Group II to the Fourth Assessment Report of the Intergovernmental Panel on Climate Change. Cambridge, UK and New York, Cambridge University Press.

[7] UNFCCC, Ecosystem-based approaches to adaptation: compilation of information. Note by the Secretariat. Available at $<$ http://unfccc.int/resource/docs/2011/sbsta/eng/inf08.pdf $>$ (2011)

[8] Galloway McLean, K. (2010). Advance Guard: Climate change impacts, adaptation, mitigation and indigenous peoples. A compendium of case studies. UNU-IAS. 
[9] Ohmagari, K. \& Berkes, F. (1997). Transmission of indigenous knowledge and bush skills among the Western James Bay Cree women of subarctic Canada. Human Ecology 25: 197222

[10] Hunn, E. (1993). What is traditional ecological knowledge? In: Williams N. and Baines G. (Eds.). Traditional ecological knowledge: Wisdom for sustainable development. Centre for Resource and Environmental Studies, ANU, Canberra, pp. 3-15.

[11] Robinson, J. \& Herbert, D. (2001). Integrating climate change and sustainable development. International Journal of Global Environmental Issues, 1(2), 130-148.

[12] Berkes, F. (1999). Sacred ecology. Traditional ecological knowledge and resource management. Taylor and Francis, Philadelphia and London, UK.

[13] Lawerence, D. \& Schlesinger. W.H. (2001). Changes in soil phosphorus during 200 years of shifting cultivation in Indonesia, Ecology 82:2769-2780.

[14] Eastmond, A. \& Faust, B. (2006). Farmers, fires, and forest: a green alternative to shifting cultivation for conservation of the Maya forest? Landsc Urban Plan 74:267-284.

[15] Thomaz, E.L. (2009). The influence of traditional steep land agricultural practices on runoff and soil loss, Agric. Ecosyst. Environ. 130:23-30.

[16] Craswell, E.T., Sajjapongse, A., Howlett, D.J.B. \& Dowling, A.J. (1997). Agroforestry in the management of sloping lands in Asia and the Pacific. Agrofor Syst. 38:121-137

[17] FAO. (1957). Shifting Cultivation, Unasylva, 11:9-11.

[18] Dove, Michael R. (1983). Theories of swidden agriculture, and the political economy of ignorance. Agroforestry Systems 1: 85-99.

[19] IWGIA. (2007). Development-induced resettlement and social suffering in Laos. Indigenous Affairs 4/07. Copenhagen: IWGIA, p. 32, p. 26.

[20] Forsyth, T. \& Andrew W. (2008). Forest Guardians, Forest Destroyers. The Politics of Environmental Knowledge in Northern Thailand. Chiang Mai, Thailand Silkworm Books

[21] Fox, J., Fujita, Y., Ngidang, D., Peluso, N., Potter, L., Sakuntaladewi, N., Sturgeon, J. \& Thomas, D. (2009) Policies, Political-Economy and Swidden in Southeast Asia. Human Ecology, 37:305-322.

[22] Nakashima, D. \& Roué, M. (2002). Social and economic dimensions of global environmental change, In: Encyclopedia of Global Environmental Change, P. Timmerman (Eds.), John Willey and Sons, pp- 314-324, Vol: 5.

[23] Conklin, H.C. (1957). Hanunoo Agriculture: a report on an integral system o f shifting cultivation in the Philippines. Rome: FAO (Forestry Development Paper no. 12

[24] Kerkhoff, E. \& Sharma E. (2006). Debating Shifting Cultivation in the Eastern Himalayas:Farmers' Innovations as Lessons for Policy, Kathmandu: ICIMOD.

[25] Geist, H.J. \& Lambin, E.F. (2001). What Drives Tropical Deforestation? A meta-analysis of proximate and underlying causes of deforestation based on subnational case study evidence. LUCC Report Series No. 4., 2001, Louvain-la-Neuve: CIACO.

[26] Brady N.C. (1996). Alternatives to slash-and-burn: a global imperative. Agriculture, Ecosystems \& Environment, 58: p. 3-11.

[27] Rastogi, M., Singh, S. \& Pathak, H. (2002). Emission of carbon dioxide from soil. Current Science, 82(5), 510-517. 
[28] Warner, K. (1991). Shifting Cultivators, Local technical knowledge and natural resource management in humid tropics. Food and Agriculture Organization of the United Nations, Via delle Terme di Caracalla, 00100 Rome, Italy.

[29] Cairns, M. \& Garrity, D.P. (1999). Improving shifting cultivation in Southeast Asia by building on indigenous fallow management strategies. Agrofor. Syst. 47:37-48.

[30] Brunn, T.B., de Neergaard, A., Lawrence, D. \& Ziegler, A.D. (2009). Environmental consequences of the demise in swidden cultivation in Southeast Asia: carbon storage and soil quality. Humn. Ecol. 37:375-388.

[31] Ziegler, A.D., Bruun, T.B., Guardiola-Claramonte, M., Giambelluca, T.W., Lawrence, D., Lam, N.T. (2009). Environmental consequences of the demise in Swidden cultivation in montane mainland Southeast Asia: hydrology and geomorphology, Humn. Ecol. 37:361-373.

[32] Sobrevila, C. (2008). Role of Indigenous People in Biodiversity Conservation. The International Bank for Reconstruction and Development / THE WORLD BANK, $1818 \mathrm{H}$ Street, N.W. Washington, D.C. 20433, U.S.A

[33] Ramakrishnan, P.S. (1992). Shifting Agriculture and Sustainable Development: an interdisciplinary study from north-eastern India. MAB Series, Volume 10, UNESCO, Paris.

[34] Mugati, T. \& Maposa, R.S. (2012). Indigenous weather forecasting: A phenomenological study engaging the shone of Zimbabwe. The Journal of Pan African Studies, 4(9), 102-111.

[35] Cox, J.L. (1992). An Introduction to the Phenomenology of Religion, Gweru: Mambo Press.

[36] Gupta, V. (2004). Community forest management - A case study of East Kameng district, Arunachal Pradesh, India, Consultancy report, CFMWG-NEI, NEHU, Shillong, India and Community Forestry International Inc., Santa Barbara, USA.

[37] Jini, D., Bhagawati, K., Singh, R., Bhagawati, R., Alone, R.A. \& Ngachan, S.V. (2015). Lura - Indigenous Approach to Biodiversity Conservation by Temporary Community Confinement of Mithuns (Bos frontalis) during Growing Season. International Letters of Natural Sciences, 44:45-53. doi:10.18052/ www.scipress.com/ILNS.44.45.

[38] Terborgh, J. (1999). Requiem for nature. Island Press, Washington, D.C.

[39] Tanaka, S., Wasli, M.E., Seman, L., Jee, A., Kendawang, J.J. \& Sakurai, K. (2007). Ecological study on site selection for shifting cultivation by the Iban of Sarawak, Malaysia. A case study in Mujong River area. Tropics, 16:357-372

[40] Nimachow, G. (2003). Akas and their forest: A study on traditional management of forest resources, Arunachal University Research Journal 6(2): 82.

[41] Swanson, T. (2013) Global Action for Biodiversity Conservation: An International Framework for Implementing the Convention on Biological Diversity, Earth Scan, London.

[42] Fairhead, J., and Leach, M. (1996). Misreading the African landscape: society and ecology in a forestsavannah mosaic. Cambridge University Press, Cambridge, UK.

[43] Iltis, H (1988). 'Serendipity in the Exploration of Biodiversity', in Wilson, E.O. (ed) Biodiversity, National Academy Press: Washington, DC.

[44] Eltringham, S.K. (1984).Wildlife Resources and Economic Development, John Wiley: New York

[45] Mao, A.A., Hynniewta, T.M. \& Sanjappa, M. (2009). Plant wealth of Northeast India in reference to ethnobotany. Indian Journal of Traditional Knowledge, 8(1):96-103. 
[46] Lane, A. \& Jarvis, A. (2007). Changes in climate will modify the geography of crop suitability: Agricultural biodiversity can help with adaptation. Paper presented at ICRISAT/CGIAR 35th Anniversary Symposium, "Climate-Proofing Innovation for Poverty Reduction and Food Security", 22-24 November 2007, ICRISAT, Patancheru, India. Available at: http://www. icrisat.org/ Journal/ SpecialProject/ sp2.pdf.

[47] Clark, C.(1973) 'Profit Maximisation and the Extinction of Animal Species', Journal of Political Economy, 81(4):950-61

[48] Warren, D.M. (1995). Comments on articles by Arun Agrawal. Indigenous Knowledge and Development Monitor 4(1):13

[49] Sporrong, U. (1998). Dalecarlia in Central Sweden before 1800: a society of social and ecological resilience. Pages 67-94 in F Berkes and C. Folke, editors. Linking social and ecological systems: management practices and social mechanisms for building resilience. Cambridge University Press, Cambridge, UK.

[50] Padoch, C., Coffey, K., Mertz, O., Leisz, S.J., Fox, J. \& R.L. Wadley. (2007).The Demise of Swidden in Southeast Asia? Local Realities and Regional Ambiguities. Danish Journal of Geography 107(1): 29-41.

[51] Jackson, W.J. \& Moore, P.F. (1998). The role of indigenous use of fire in forest management and conservation. International Seminar on Cultivating Forests: Alternative Forest Management Practices and Techniques for Community Forestry, Regional Community Forestry Training Center, Bangkok, Thailand.

[52] Lewis, H.T. (1989). Ecological and Technological Knowledge of Fire: Aborigines Versus Park Rangers in Northern Australia. American Anthropologist 91(4).

[53] Giardina, C.P., Sanford Jr, R.L,. Døckersmith, I.C. \& Jaramillo, V.J. (2000). The effects of slash burning on ecosystem nutrients during the land preparation phase of shifting cultivation. Plant and Soil, 220: 247-260.

[54] Tanaka, S., Kendawang, J.J., Ishihara, J., Shibata, K., Kou, A., Jee, A., Ninomiya, I. \& Sakurai, K. (2004). The effects of shifting cultivation on soil ecosystems in Sarawak, Malaysia. II. Changes in soil chemical properties and runoff water at Balai Ringin and Sabal Experimental sites. Soil Science and Plant Nutrition, 50: 689-699.

[55] Tanaka, S., Kendawang, J.J., Yoshida, N., Shibata, K., Jee, A., Tanaka, K., Ninomiya, I. \& Sakurai, K. (2005). Effects of shifting cultivation on soil ecosystems in Sarawak, Malaysia. IV. Chemical properties of the soils and runoff water at Niah and Bakam experimental sites. Soil Science and Plant Nutrition, 51: 525-533.

[56] Kleinman, P. J. A., Pimentel D. \& Bryant, R.B. (1995). The ecological sustainability of slashand-burn agriculture. Agriculture, Ecosystems and Environment, 52(2-3): 235-249.

[57] Myers, N. (1992). The Primary Source: Tropical Forests and Our Future, W. W. Norton, New York.

[58] Giri, T. (2007). Strengthening Monitoring, Assessment and Reporting on Sustainable Forest Management in Asia (GCP/INT/988/JPN). Forest Department, Food and Agriculture Organization of the United Nation, Rome.

[59] Erni, C. (2009). Shifting the blame? Southeast Asia's indigenous peoples and shifting cultivation in the age of climate change. Paper presented at the seminar on "Adivasi/ST Communities in India: Development and Change", Delhi, August 27-29, 2009, p. 6

[60] Van Noordwijk M., Mulyoutami, E., Sakuntaladewi, N., \& Agus, F. (2008). Swiddens in transition: shifted perceptions on shifting cultivators in Indonesia. Occasional Paper no.9. Bogor, Indonesia: World Agroforestry Centre. 
[61] Fearnside, P.M. (2000). Global warming and tropical land-use change: Greenhouse gas emissions from biomass burning, decomposition and soils in forest conversion, shifting cultivation and secondary vegetation, Clim. Change, 46:115-158, doi:10.1023/A:1005569915357.

[62] Lehsten, V., Tansey, K., Balzter, H., Thonicke, K., Spessa, A., Weber, U., Smith, B. \& Arneth. A. (2009). Estimating carbon emissions from African wildfires, Biogeosciences, 6: 349-360, doi:10.5194/bg-6-349-2009.

[63] Intergovernmental Panel on Climate Change (IPCC). (2006). Land Use, Land-Use Change and Forestry. IPCC, http://www.grida.no/publications/other/ipcc_sr/?src=/climate/ ipcc/land_use/008.htm\#s6-1

[64] Ruthenberg, H. (1971). Farming Systems in the Tropics. Oxford: Clarendon Press.

[65] La Scala, N., Bolonhezi, D. \& Pereira, G.T. (2006). Short-term soil CO2 emission after conventional and reduced tillage of a no-till sugar cane area in southern Brazil. Soil Till. Res. 9:244-248.

[66] Noel, D.U. \& Herby, B. (2000). Global climate change and the effect of conservation practices in US agriculture. Global Environmental Change 10:197-209.

[67] Wan, Y.F. \& Lin, E.D. (2004). The influence of tillage on CH4 and CO2 emission flux in winter fallow cropland. Chinese Journal of Agrometeorology 3:8-10

[68] Gafur, A. (2001). Effects of shifting cultivation on soil properties, erosion, nutrient depletion and hydrological responses in small watershed of Chittagong Hill Tracts, unpublished $\mathrm{PhD}$ dissertation, Chemistry Department, The Royal Veterinary and Agricultural University, Copenhagen, Denmark.

[69] Gafur, A. Borggaard, O.K., Jensen, J.R. \& Peterson, L. (2003) Run off and loses of soil and nutrients from watershed under shifting cultivation (Jhum) in the Chittagong Hill Tracts of Bangladesh. J. Hydrol., 279:293-309.

[70] Aryal, K.P. \& Kerkhoff, E. (2008). The right to practice shifting cultivation as a traditional occupation in Nepal. A case study to apply ILO Conventions No. 111 (Employment and Occupation) and 169 (Indigenous and Tribal peoples) Kathmandu, International Labour Office.

[71] Solow, R. (1974). 'The Economics of Resources or the Resources of Economics', American Economic Review, 64:1-12.

[72] Gliessman, S.R. (1985). Economic and ecological factors in designing and managing sustainable agroecosystems. In Edens, T. C., Fridgen, C. and Battenfield, S. L. (eds.) Sustainable agriculture and integrated farming systems. East Lansing: Michigan State University Press, pp. 56 - 63. 